\title{
ECONOMICS OF FRESH WATER PRAWN FARMING IN SOUTHWEST REGION OF BANGLADESH
}

\author{
F. Yasmin ${ }^{1}$, M. Hossain ${ }^{2}$, M. S. Islam ${ }^{3}$ and M. H. A. Rashid ${ }^{4}$ \\ Department of Agricultural Economics, Bangladesh Agricultural University \\ Mymensingh-2202, Bangladesh
}

\begin{abstract}
This study was designed to assess the profitability of freshwater prawn farming in gher systems in southwest Bangladesh. Four Upazilas namely: Bagerhat Sadar, Fakirhat, Mollahat and Chitalmari were purposely selected from Bagerhat district. Primary data were collected from randomly selected 100 gher owners. Results of the financial analyses indicate that investment in all the selected golda farming projects is profitable. On an average, total cost of FPF was Tk. 80,301.00 per hectare and average gross return per hectare per year stood at Tk. 216,400.00 and the gross margin per hectare per year was Tk. 205,278.00. The net return per hectare per year was Tk. 136,099.00. Although farmers in the study areas were facing different problems, it was concluded that the freshwater prawn farming is sustainable and it did not have any deleterious effect on environment. Finally, based on the findings of the study, some recommendations were made for the development of sound freshwater prawn farming in Bangladesh.
\end{abstract}

Key Words: Sustainability, Prawn, Environmental aspect

\section{INTRODUCTION}

The fisheries sub-sector is of critical importance to the economy of Bangladesh. This sector plays an important role in supplying nutrition, creation of rural employment, poverty alleviation and earning foreign exchange. In Bangladesh, fish provides 74 per cent of animal protein consumption and about 1.2 million people are directly employed in this sector. Another 10.8 million people indirectly earn their livelihood out of activities related to fisheries. The fisheries sector contributes 4.73 per cent of Gross Domestic Product (GDP) and about 4.04 per cent to foreign exchange earning through export. This sector employs about 7 per cent of the national labour force (DoF, 2008).

\footnotetext{
${ }^{1}$ Ex-post graduate student, Department of Agricultural Economics, Bangladesh Agricultural University, Mymensingh-2202, Bangladesh

2 Lecturer, Department of Agricultural Economics, Bangladesh Agricultural University, Mymensingh-2202, Bangladesh

3 Scientific Officer, Bangladesh Fisheries Research Institute, Mymensingh

4 Professor, Department of Agricultural Economics, Bangladesh Agricultural University, Mymensingh-2202, Bangladesh
} 
The freshwater prawn, locally known as golda, is a highly valued product for international markets. Almost all prawns are therefore exported, particularly to the USA, Japan and Europe. Freshwater prawn farming is mostly concentrated in southwest Bangladesh mainly Khulna, Bagerhat and Satkhira districts. In southwest Bangladesh, thousands of farmers have converted their paddy fields to 'ghers' to accommodate a profitable prawn culture practice.

Freshwater prawn (M. rosenbergii) farming is currently one of the most important sectors of the national economy and during the last two decades, its development has attracted considerable attention because of its export potential. The prawn and shrimp sector as a whole is the second largest export industry after readymade garments, generating US\$ 380 million annually and $5.6 \%$ of the total value of exports (DoF, 2006). There are 1.2 million people employed in fish and shrimp production and a further 4.8 million household members are associated with the sector (USAID, 2006). Despite the growth of this sector, a number of issues are important for freshwater prawn farming in Bangladesh including production technology, socioeconomic and environmental aspects. All of these are important parameters of sustainability.

Traditional "gher" aquaculture had been practiced in the tidal area of Bangladesh to grow shrimp with fish long before the introduction of current shrimp culture practice which is to some extent, a modification of the traditional "gher" aquaculture. In the early 1960s, the government constructed a large number of coastal embankments to protect the agricultural land in the coastal area from tidal waves and saline water intrusion. This coastal embankment project implemented by Bangladesh Water Development Board (BWDB) made vast saline areas suitable for rice cultivation. These embankments brought an end to the "gher" shrimp culture mainly due to its strong demands in international markets and its high price. Equally important was the fact that, by that time it was no more financially viable to cultivate rice in several polders because they had become water logged due to poor drainage. These two factors together provided a catalyst to the process of accelerated shrimp farming (Karim, 1989).

Thus, it is believed that the present study will contribute significantly in adding new knowledge in the field of agricultural production policy. This study deals with some hitherto uncovered issues and hence may be considered important both for farmers and policy makers view points. However, this study is intended to deal with the following specific objectives:

To determine the cost, return and profitability of freshwater prawn farming;

To assess the sustainability and environmental aspects of freshwater prawn farming under gher systems; and

To suggest some policy guidelines and/or recommendation. 


\section{METHODOLOGY}

\section{The Data and sampling technique}

The study was undertaken in 4 Upazilas of Bagerhat district, the southwest part of the country, namely Bagerhat Sadar, Fakirhat, Mollahat and Chitalmari to cover a sample of 100 prawn farmers who were randomly selected. In addition, some relevant information was also collected from a group of well-to-do farmers with economic solvency, through focus group discussion (FGD). This study covered the whole production period of freshwater prawn culture from July 2008 to June 2009.

Secondary data was collected through literature and publications available at BFRI library, website, publications of project advisor and program officers, monthly, quarterly and annual reports; Books of Bangladesh Bureau of Statistics, government and nongovernment organizations involved with aquaculture.

\section{Analytical techniques}

For making a lucid and meaningful analysis of assessment of the sustainability of freshwater prawn farming in gher system in southwest Bangladesh, following statistical tools were used. Some statistical measures like average, percentage and ratios were calculated and presented in different tables. In this study, costs and returns analyses were done on both variable and total cost basis. The following profit $(\pi)$ equation was used to assess profitability of integrated prawn farming:

$$
\pi=P_{p} Q_{p}+P_{c} Q_{c}+P_{s} Q_{s}-\Sigma\left(P_{x i} \cdot X_{i}\right)-T F C
$$

Where,

$$
\begin{aligned}
& \pi=\text { profit per hectare of freshwater prawn farm } \\
& P_{p}=\text { per unit price of prawn }(\mathrm{Tk} / \mathrm{kg}) \\
& \mathrm{Q}_{\mathrm{p}}=\text { quantity of prawn }(\mathrm{kg} / \mathrm{ha}) \\
& \mathrm{P}_{\mathrm{c}}=\text { per unit price of carp fish }(\mathrm{Tk} / \mathrm{kg}) \\
& \mathrm{Q}_{\mathrm{c}}=\text { quantity of carp fish }(\mathrm{kg} / \mathrm{ha}) \\
& \mathrm{P}_{\mathrm{s}}=\text { per unit price of small indigenous species }(\mathrm{SIS})(\mathrm{Tk} / \mathrm{kg}) \\
& \mathrm{Q}_{\mathrm{s}}=\text { quantity of SIS }(\mathrm{kg} / \mathrm{ha}) \\
& \mathrm{P}_{\mathrm{xj}}=\text { per unit price of } \mathrm{i} \text {-th }(\mathrm{variable}) \text { inputs } \\
& \mathrm{X}_{\mathrm{i}}=\text { number } / \text { quantity of } \mathrm{i} \text {-th inputs } \\
& \mathrm{i}=(1,2,3, \ldots, \mathrm{n}) \text { and } \\
& \mathrm{TFC}=\text { Total fixed cost. }
\end{aligned}
$$

\section{RESULTS AND DISCUSSION}

For every production process, cost plays a vital role for making right decision of the farmers. The costs were classified into variable costs and fixed costs. In this study, variable cost items included were human labour, fingerlings, fertilizer, manure, irrigation, feed, lime, insecticides etc. Farmers of the study area used both purchased and 
home supplied inputs for golda shrimp production. Both inputs and outputs were valued at the farm gate prices. It was easier for a farmer to determine the cost of purchased inputs but it was not so simple to determine the cost of home supplied inputs such as: family labour, feed for which no payment was actually made. In estimating the cost of such home supplied inputs, the principle of opportunity cost was followed in the study.

\section{Variable Cost}

\section{Human labour costs}

Total human labour required and their costs per hectare in different operations for yearround golda shrimp farming presented in Table 3.1. It appears from the table that the total human labour employed per hectare per year was 148 man days, of which 60.0 man-days were family supplied and 88.0 man-days were hired labour. Total per hectare costs of human labour for all operations was Tk. 20580.00 (Table 1 and 2). The highest costs per hectare of human labour were incurred for harvesting and gher supervision.

Table 1. Use of human labour and its cost per hectare for year-round golda farming

\begin{tabular}{l|c|c|c|c|c}
\hline \multicolumn{1}{c|}{ Items } & $\begin{array}{c}\text { Family } \\
\text { labour } \\
(\mathrm{man}- \\
\text { day/ha) }\end{array}$ & $\begin{array}{c}\text { Hired } \\
\text { labour } \\
(\mathrm{man}- \\
\text { day/ha })\end{array}$ & $\begin{array}{c}\text { Price } \\
\text { (Tk/man- } \\
\text { day })\end{array}$ & $\begin{array}{c}\text { Total } \\
\text { cost } \\
(\mathrm{Tk} / \mathrm{ha})\end{array}$ & $\begin{array}{c}\% \text { of } \\
\text { total }\end{array}$ \\
\hline Land preparation & 8 & 16 & 140 & 3360 & 16.33 \\
Canal digging and making embankment & - & 30 & 130 & 3900 & 18.95 \\
Application of shrimp feed and shrimp seeds & 7 & 5 & 130 & 1560 & 7.58 \\
Management and-supervision & 15 & 12 & 150 & 4050 & 19.68 \\
Fertilizer use and lime use & 5 & 7 & 130 & 1560 & 7.58 \\
Harvesting & 25 & 16 & 150 & 6150 & 29.88 \\
\hline Total & 60 & 88 & & 20580 & 100.00 \\
\hline
\end{tabular}

Source: Field Survey (2009)

\section{Cost of post-larvae (PL)}

Golda shrimp farmers in the study area mainly used purchased (PL). Per hectare costs of PL were Tk. 25000.00 for year round shrimp (Table 2).

\section{Cost of fertilizers and manures}

In the study area, farmers used Urea and TSP as fertilizer and cowdug as manure to increase production of natural feeds. Per hectare costs of manure were calculated at Tk. 194.00 for year-round golda shrimp culture which has shown in Table 2. The cost of fertilizer has shown in Table 2 as well. 


\section{Cost of feed}

In the study area, it was observed that the shrimp farmers used different kinds of supplementary feeds which were: rice bran, wheat bran. Per hectare costs of feed were calculated at Tk. 3000.00 for year-round golda farming (Table 2).

Table 2. Per hectare variable cost of year-round golda farming

\begin{tabular}{|c|c|c|c|c|c|}
\hline Variable cost items & Units & Quantity & $\begin{array}{l}\text { Price/Unit } \\
\text { (Tk) }\end{array}$ & $\begin{array}{c}\text { Total } \\
\text { Cost (Tk/ha) }\end{array}$ & $\begin{array}{c}\text { Per cent } \\
\text { of total cost }\end{array}$ \\
\hline Human labour & Man-day & 148.00 & 140.00 & 20580.00 & 38.31 \\
\hline $\begin{array}{l}\text { Cost of shrimp seed and fin } \\
\text { fish fingerlings }\end{array}$ & Nos. & 10000.00 & 2.5 & 25000.00 & 46.54 \\
\hline \multicolumn{6}{|l|}{ Fertilizer: } \\
\hline Urea & $\mathrm{kg}$ & 33.00 & 12.00 & 396.00 & 0.74 \\
\hline TSP & $\mathrm{Kg}$ & 11.00 & 32.00 & 352.00 & 0.66 \\
\hline Manure (cowdung) & $\mathrm{Kg}$ & 194.00 & 1.00 & 194.00 & 0.36 \\
\hline Feed & $\mathrm{Kg}$ & 120.00 & 25 & 3000.00 & 5.58 \\
\hline Lime & $\mathrm{Kg}$ & 150.00 & 15 & 2250.00 & 4.10 \\
\hline Miscellaneous cost & & - & - & 2000.00 & 3.72 \\
\hline Total variable cost & & & & 53722 & 100.00 \\
\hline
\end{tabular}

Source: Field Survey (2009)

\section{Cost of lime}

Application of lime in the water body is very important for shrimp farming. In the study area, most of the farmers used $150 \mathrm{~kg} /$ ha for year-round golda shrimp farming against the requirement of $247 \mathrm{~kg} / \mathrm{ha}$. Average per hectare costs of lime was calculated at Tk. 2250.00 .

\section{Miscellaneous cost}

Miscellaneous costs included all incidental expenses paid by the farmers for producing golda shrimp. In the study area, per hectare miscellaneous costs for year-round golda shrimp farming was Tk. 2000.00 (Table 2).

\section{Fixed cost}

Firstly, land use cost for year-round golda shrimp farming were estimated Tk. 19,000.00 per hectare on the basis of yearly rental value in the study area. Secondly, per hectare cost of canal digging and making boundary dam was estimated at Tk. 2174.00 which shared 8.18 per cent of total fixed cost. Thirdly, per hectare average cost for making guard sheds was computed at Tk. 1239.00. Furthermore, per hectare average cost of nets and other equipments were calculated at Tk. 619.00. Finally, the following formula was used for the calculation of interest on operating capital (Miah 1987):

$$
\text { Interest on operating capital }=\text { AIit }
$$


Where,

$\mathrm{AI}=($ Total investment $) / 2$;

$\mathrm{I}=$ interest rate per year (i.e., 14 per cent); and

$\mathrm{t}=$ length of the production period (12 month)

In the study area, interest on operating capital was estimated at Tk. 1762.00 for year-round golda shrimp farming (Table 3).

Table 3. Per hectare fixed costs of year-round golda farming

\begin{tabular}{lcc}
\hline \multicolumn{1}{c|}{ Cost items } & Cost (Tk/ha) & Per cent $(\%)$ \\
\hline Land use cost & 19000.00 & 71.49 \\
Canal digging and making boundary dam & $21,74.00$ & 8.19 \\
Making guard sheds & 1239.00 & 4.66 \\
Nets and other equipment & 619.00 & 2.33 \\
Interest on operating capital (14\%) & 1762.00 & 6.63 \\
\hline Total fixed cost & 26579.00 & 100.00
\end{tabular}

Source: Field Survey (2009)

\section{Gross cost}

The total gross costs were calculated by adding up total variable cost and total fixed cost. Per hectare total gross costs of the selected golda shrimp farming is presented in Table 4 . It is evident from Table 6.4 that per hectare per year total costs for year-round golda farming was (Tk. 80301.00).

Table 4. Per hectare total cost of year-round golda farming

\begin{tabular}{lcc}
\multicolumn{1}{c|}{ Cost items } & Cost (Tk/ha) & Per cent \\
\hline Total variable cost & 53722.00 & 66.90 \\
Total fixed cost & 26579.00 & 33.10 \\
\hline Total cost & 80301.00 & 100 \\
\hline
\end{tabular}

Source: Field Survey (2009)

\section{Yield and return of year-round golda farming}

In the study area, per hectare per year yield of shrimp was $452 \mathrm{~kg}$ (Tables 5). It may be noted here that per unit price of shrimp $(\mathrm{Tk} / \mathrm{kg})$ varies from one category to another which depends on the size of individual shrimps. According to shrimp processors of the study area, these categories have been identified as Grade 'A' ( $<16$ shrimps make one $\mathrm{kg}$ ), Grade 'B' (16-30 shrimps make one kg), Grade 'C' (30-40 shrimps make one kg) and Grade 'D' (more than 40 shrimps make one kg). Farmers sell their outputs (i.e. golda shrimp) in the local market. So, farm gate price was considered for valuing yields. The average farm 
gate prices of shrimp of Grade 'A', Grade 'B', Grade 'C' and Grade 'D' were Tk. 530.00/kg, Tk. $400.00 / \mathrm{kg}$, Tk. $350.00 / \mathrm{kg}$ and Tk. $260.00 / \mathrm{kg}$ respectively.

Table 5. Per hectare return of year-round golda farming

\begin{tabular}{|c|c|c|c|c|}
\hline Items & $\begin{array}{c}\text { Yield } \\
(\mathrm{kg} / \mathrm{ha})\end{array}$ & $\begin{array}{c}\text { Price } \\
(\mathrm{Tk} / \mathrm{kg})\end{array}$ & $\begin{array}{c}\text { Gross } \\
\text { income }(\mathrm{kg} / \mathrm{ha})\end{array}$ & $\begin{array}{c}\text { Per cent of } \\
\text { total gross income }\end{array}$ \\
\hline \multicolumn{5}{|l|}{ Gross income : } \\
\hline \multicolumn{5}{|l|}{ Golda shrimp : } \\
\hline A - grade & 180 & 530.00 & 95400.00 & 44.09 \\
\hline B - grade & 120 & 400.00 & 48000.00 & 22.18 \\
\hline $\mathrm{C}$ - grade & 75 & 350.00 & 26000.00 & 12.01 \\
\hline D - grade & 77 & 260.00 & 20000.00 & 9.24 \\
\hline Sub-total & 452 & - & 189400 & 87.52 \\
\hline Fin fish & 180 & 150 & 27000 & 12.48 \\
\hline $\begin{array}{l}\text { Gross return from golda } \\
\text { shrimp and fin fish }\end{array}$ & - & - & 216400 & 100 \\
\hline Total cost & & & 80301 & - \\
\hline Net return & & & 136099 & \\
\hline
\end{tabular}

Source: Field Survey (2009)

It can be seen from Table 3.5 that gross return for year-round golda farming was Tk. 216400.00 and per hectare net return or profit were computed by subtracting per hectare gross costs from its per hectare gross returns. The net returns were Tk. 136099.00 for year-round golda shrimp farming.

\section{Benefit-cost ratio (Undiscounted)}

Average return to each Taka spent in production is a vital criterion for measuring the profitability of growing any enterprise. In this study, BCR (undiscounted) is the ratio of per hectare gross returns and gross costs. In the case of year-round golda farming BCR was 2.69. It is relative measure, used to compare benefit per unit of cost. Here BCR was used to see the profitability of production.

\section{Sustainable golda shrimp farming and environment}

Sustainable aquaculture should aim at overall economic development. But economic development can induce irreversible damage to fragile ecosystems. In situations where the economic and environmental are so deeply interconnected, economic development can be feasible only under a system of sustainable development (WCED 1987). In fresh water aquaculture, there was no significant impact on ecosystem and environment. Almost all the farmers reported that, the present aquaculture practices and its long-term continuation did not affect environment and to some extent, biodiversity in farming areas rather it protects the environment (Table 6). As a result, some farmers in different areas of 
Bangladesh shifted their crop land into fish farm. Moreover, freshwater aquaculture is preferred by all the farmers which is socially acceptable also.

Table 6. Causes of sustainability and promotion of freshwater prawn (golda) farming

\begin{tabular}{l|c|c|c|c}
\hline $\begin{array}{c}\text { Categories of } \\
\text { farmers }\end{array}$ & $\begin{array}{c}\text { Environment } \\
\text { friendly }\end{array}$ & $\begin{array}{c}\text { Low mortality } \\
\text { rate }\end{array}$ & $\begin{array}{c}\text { Socially } \\
\text { acceptable }\end{array}$ & $\begin{array}{c}\text { Environmental } \\
\text { protection }\end{array}$ \\
\hline Small & 96 & 68 & 99 & 60 \\
Medium & 95 & 74 & 97 & 50 \\
Large & 94 & 72 & 94 & 57 \\
\hline All (average) & 95 & 71 & 97 & 56 \\
\hline
\end{tabular}

Source: Field Survey (2009)

\section{CONCLUSION AND RECOMMENDATIONS}

It may be concluded that integrated prawn farming is highly profitable. Bangladesh is considered one of the most suitable countries in the world for giant freshwater prawn (Macrobrachium rosenbergii) farming, because of its favourable resources and agro-climatic conditions. A sub-tropical climate and a vast area of water bodies provide a unique opportunity for the production of Macrobrachium spp. If modem inputs and production technology can be made available to farmers in time, then yield and production of FPF may be increased which can help the farmers to increase income and improve livelihood conditions. FPF can help in improving the nutritional status of the rural people. Therefore it may be, concluded that where there is lot of paddy field and irrigation facilities, farmers can profitably produce FPF instead of only rice crops. Further, in the areas where land is flood free, production of FPF can be under taken to increase income and employment opportunities of the farmers. The domestic and foreign consumption of FPF is likely to increase in future. The present and future potential market and demand for prawn should be determined through a comprehensive study in order to take up a wellplanned prawn production programme at national level.

\section{REFERENCES}

Asaduzzaman M.,Wahab M.A.,Yi Y., Diana J.M. and Lin C.K. (2007) Bangladesh prawn-farming survey reports industry evaluation. Global Aquaculture Advocate, 9: 40-43.

BBS, (2007). Statistical Year Book of Bangladesh, Bangladesh Bureau of Statistics, Ministry of Planning, Government of the People's Republic of Bangladesh, Dhaka.

DoF (2006) Fishery Statistical Yearbook of Bangladesh 2004- 2005. Fisheries Resources Service System, Department of Fisheries (DoF), Ministry of Fisheries and Livestock, Dhaka, Bangladesh, 42 p. 
DoF (2008) Fishery Statistical Yearbook of Bangladesh. Fisheries Resources Service System, Department of Fisheries (DoF), Ministry of Fisheries and Livestock, Dhaka, Bangladesh.

Karim, M. (1989), Present status, scopes and constraints of Macrobrachium rosenbergii culture in of the Fisheries section. FAO/UNDP, Department of Fisheries, Bangladesh.

Miah M. T. H. and Hardaker, J. B. (1987), Benefit-cost analysis of deep and shallow tube well projects in the Tangail District in Bangladesh, Bangladesh J. Agril. Econ. 11(1): pp. 1-29.

USAID. 2006. A Pro-Poor Analysis of the Shrimp Sector in Bangladesh. The United States Agency for International Development (USAID), Development and Training Services, Arlington, VA, $93 \mathrm{p}$.

WCED. 1987 Our Common future world Commission on Environment and Development Oxford University Press, New York. p. 400. 